\title{
SISTEM INFORMASI PENJUALAN SEPATU BERBASIS WEB PADA TOKO STEPHEN SPORTS
}

\author{
${ }^{1}$ Sofyan, ${ }^{2}$ Usman \\ ${ }^{12}$ Program Studi Sistem Informasi, Fakultas Teknik dan Ilmu Komputer \\ Universitas Islam Indragiri (UNISI) \\ Jl. Parit 1 Tembilahan Hulu, Tembilahan Riau \\ Email : msofyan1997@gmail.com, usmanovsky13411@gmail.com
}

\begin{abstract}
ABSTRAK
Penjualan online toko sepatu menjadi peluang yang sangat baik dalam dunia E-commerce. Bagaimana tidak, produk toko sepatu yang dijual merupakan produk yang sangat di minati oleh semua kalangan. Produk yang dijual jarang ditemukan bahkan sulit ditemukan. Aplikasi yang dirancang didesain sesederhana mungkin agar mempunyai daya tarik lebih bagi pembeli, pembeli dapat berbelanja dalam waktu yang singkat tanpa harus melewati proses pendaftaran dan proses login. Aplikasi ini tidak hanya mempermudah pembeli dalam berbelanja, namun juga membantu memperluas pemasaran produk bahkan mampu membantu dalam hal laporan keuangan penjualan.

Kata kunci: E-commerce, web, system informasi
\end{abstract}

\section{PENDAHULUAN}

Toko Stephen merupakan sebuah Toko Sport, Produk yang ditawarkan Toko Stephen ini mempunyai beberapa kategori diantaranya seperti sepatu sport, dan yang lain - lain nya. Pemasaran produk Toko Stephen sendiri hingga saat ini semakin meningkat, bukan hanya didalam kota saja bahkan sudah meluas hampir keseluran provinsi yang ada di indonesia.

Setiap pembelian produk konsumen harus datang ke toko melihat - lihat dan memilih langsung atau dengan cara pembelian online melalui media bbm dan facebook saat ini digunakan Toko Stephen untuk memasakan produknya. Namun dari beberapa media itu terkadang konsumen harus menghubungi terlebih dahulu produk apa yang terbaru tanpa melihat persediaan produk yang di update dalam media tersebut. Hal ini menjadi masalah jika produk yang diinginkan konsumen tidak sesuai dengan persedian yang ada. Sebetulnya permasalahan ini bisa diatasi dimedia tersebut, hanya yang menjadi permasalahannya ada beberapa media yang toko Stephen Sport gunakan yang menyinggung efisiensi waktu dalam hal pemesanan barang. Dilihat dari menngkatannya penjualan di Toko Stephen Sport membutuhkan media yang lebih memudahkan untuk memasarkan produk, selain media pengolahan data masih dilakukan secara manual, juga ditemukan minimnya info bagi para pembeli untuk mendapatkan info seputar produk yang dijual di Toko Stephen Sport dan belum ada media yang lebih mudah mempermudah konsumen untuk melihat produk apa saja yang tersedia di Toko Stephen.

Dengan semakin terjangkaunya harga smartphone di indonesa, saat ini trend menggunakan smartphone semakin meningkat dikalangan masyarakat karena keunggulannya sendiri mempunyai fitur - fitur yang lebih membantu dan lebih praktis. Berdasarkan survei penulis, konsumen Toko Stephen sendiri kebenyakan sudah menggunakan smartphone. Guna memudahkan konsumen utuk melihat produk Toko Stephen, mendapatkan info barang terbaru dan bagaimana cara order online. Maka untuk memecahkan masalah ini diperlukan aplikasi yang khusus mengenai penjualan produk di Toko Stephen.

Android adalah sistem operasi mobile yang akhir - akhir ini menjadi trend, yang banyak digunakn oleh semua pengguna dari berbagai usia dari muda hingga tua. Pada artikel ini peneliiti ingin merancang suatu aplikasi yang dapat memberikan informasi kepada masyarakat khususnya konsumen dari Toko Stephen tentang informasi dan produk dari Steven yang diperlukan secara tepat yang melalui sebuah aplikasi untuk perangkat berbasis web. Aplikasi yang akan dibangun sendiri dapat diartikan sebuah pusat dokumentasi menggunakan aplikasi yang akan dibangun ini membuat berbelanja online menjadi singkat dan hemat tenaga. 


\section{TINJAUAN PUSTAKA \\ 2.1 Pengertian Dan Definisi Sistem}

Dalam aktivitas sehari - hari, kita pasti terlibat baik secara langsung atau tidak langsung dalam suatu sistem. Misalnya, ketika kita berangkat kekantor atau kekampus, kitapasti terlibat dalam sistem transportasi. Sebagai mahluk hidup, kita bernafas, maka setiap hari kita menggunakan sistem pernafasan. Masih banyak lagi sistem - sistem yang terlibatkan kita seperti, sistem pendidikan,sistem penerangan, dan lain sebagai nya.

Menurut jogiyanto, sistem adalah kumpulan elemen - elemen yang berinteraksi untuk mencapai suatu tujuan tertentu. (2005).

Sistem adalah kumpulan atau himpunan dari unsur atau variabel - variabel yang saling terkait, saling berinteraksi, dan saling tergantung satu sama lain untuk mencapai tujuan. (Hamim, 2014)

Selain itu sistem juga dapat dideinisikan sebagai kumpulan objek - objek yang saling berelasi dan berinteraksi, serta hubungan antar objek bisa dilihat sebagai satu kesatuan yang dirancang sebagai satu tujuan yang telah ditetapkan.

\subsection{Perancangan Sistem}

Perancangan sistem (system development) dapat berarti menyusun sistem yang baru untuk menggantikan sistem yang lama secara keseluruhan atau memperbaiki sistem yang sudah ada. Sistem yang lama perlu diperbaiki atau diganti disebabkan karena beberapa hal (Hamim, 2014):

\subsection{Informasi Dan Sistem Informasi}

Menurut sutabri, dalam bukunya sistem informasi manajemen menjelaskan bahwa, informasi merupakan data yang telah diklasifikasikan atau diolah atau diinterpretasikan untung digunakan dalam proses pengambil keputusan. (2002).

Menurut indrajit, dalam bukunya manajemen sistem informasi dan teknologi informasi penulisan bahwa, ditinjau dari pengertiannya, sistem informasi dapat dianalogikan sebagai sebuah permintaan (demand) dari masyarakat industri, ketika kebutuhan akan serana pengolahan data dan komunikasi yang cepat dan murah (menembus ruang dan waktu).(2000).

Informasi adalah data. Data adalah fakta atau kenyataan yang menggambarkan suatu kejadian kejadian yang mempunyai arti tersendiri. Informasi adalah data yang telah diproses sedemikian rupa, sehingga memiliki arti yang bermanfaat bagi penggunanya. (Hamim, 2014)

\subsection{Analisis PIECES}

Untuk mengindentifikasi masalah, maka harus dilakukan analisis terhadap kinerja, ekonomi, pengendalian, efisiensi, dan pelayanan atau juga sering disebut dengan analisa PIECES. Adapun pengertian dari analisis pieces sebagai berikut (Syafrin, 2011)

Pengertian dari masing-masing PIECES :

\section{Analisis Kinerja (performance)}

Masalah Kinerja terjadi ketika tugas-tugas yang dijalankan oleh sistem mencapai sasaran. Kinerja diukur dengan jumlah produksi dan waktu tanggap. Jumlah produksi adalah jumlah pekerjaan yang dilaksanakan selama jangka waktu tertentu. Waktu tanggap adalah keterlambatan rata-rata antara suatu transaksi dengan tanggapan yang diberikan kepada transaksi tersebut.

2. Analisis Informasi (information)

Informasi merupakan komoditas yang penting bagi pemakai akhir. Karena Informasi yang akan dihasilkan dapat memenuhi keinginan dari pengguna dan juga dapat mengatasi masalah-masalah yang ada.

3. Analisis ekonomi (economy)

Ekonomi merupakan motivasi paling umum bagi suatu lembaga. Pijakan dasar bagi kebanyakan manajer adalah biaya yang murah.

4. Analisis Pengendalian (control) 
Tugas-tugas dari sustu sistem informasi perlu di monitor dan dibetulkan jika ditemukan adanya kinerja yang di bawah standar. Kontrol dipasang untuk meningkatkan kinerja sistem, mencegah atau mendeteksi penyalahgunaan atau kesalahan sistem dan menjamin keamanan data.

5. Analisis efisiensi (efficiency)

Efisiensi berhubungan dengan bagaimana sumber tersebut digunakan dengan pemborosan yang minimal. Oleh karena itu, masalah efisiensi membutuhkan peningkatan output/hasil. Karena sistem yang ada telah dapat di daya gunakan dengan baik dan juga telah dapat menghasilkan output seusai dengan yang diharapkan.

6. Analisis Pelayanan (service)

Pelayanan yang baik dapat mencerminkan suatu lembaga itu baik atau tidak baik, sehingga pelayanan harus juga diperhitungkan secara baik.

\subsection{Data Flow Diagram (DFD)}

Merupakan alat pemodelan dari proses analisis kebutuhan perangkat lunak. Dalam DFD dibahas fungsifungsi apa saja yang diperlukan oleh suatu sistem dan aliran data yang terdapat diantara proses didalamnya. DFD berguna sebagai alat untuk memverifikasikan apakah sistem yang sudah dibangun sudah memenuhi kriteria yang diinginkan oleh user atau belum. Data Flow Diagram (DFD) memiliki 4 (empat) simbol dasar, Yaitu (Muhammad, 2012):

\section{METODOLOGI PENELITIAN}

\subsection{Diagram Context}

Berikut adalah gambar Diagram context Aplikasi Penjualan berbasis web pada Toko Stephen :

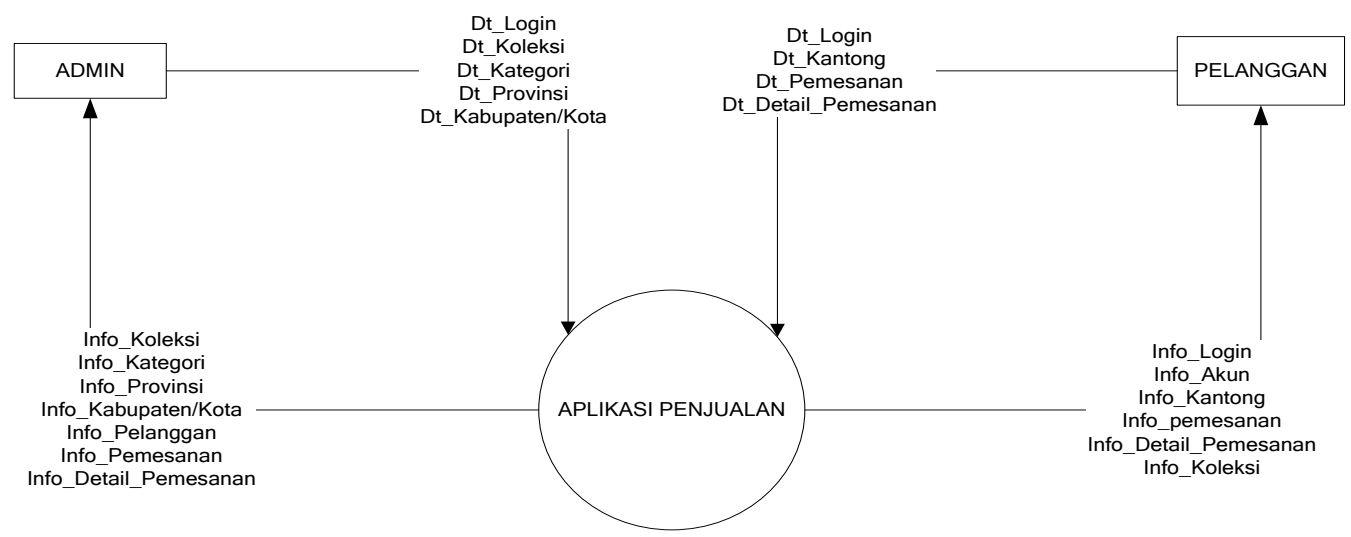

\section{Gambar 1 Diagram Context}

Gambar diatas secara umum menggambarkan bagaimana sistem terhubung dengan admin dan pelanggan. Pada gambar di atas juga dapat dilihat proses input dan output yang mampu dilakukan oleh sistem.

\subsection{Data Flow Diagram (DFD) Level 1}




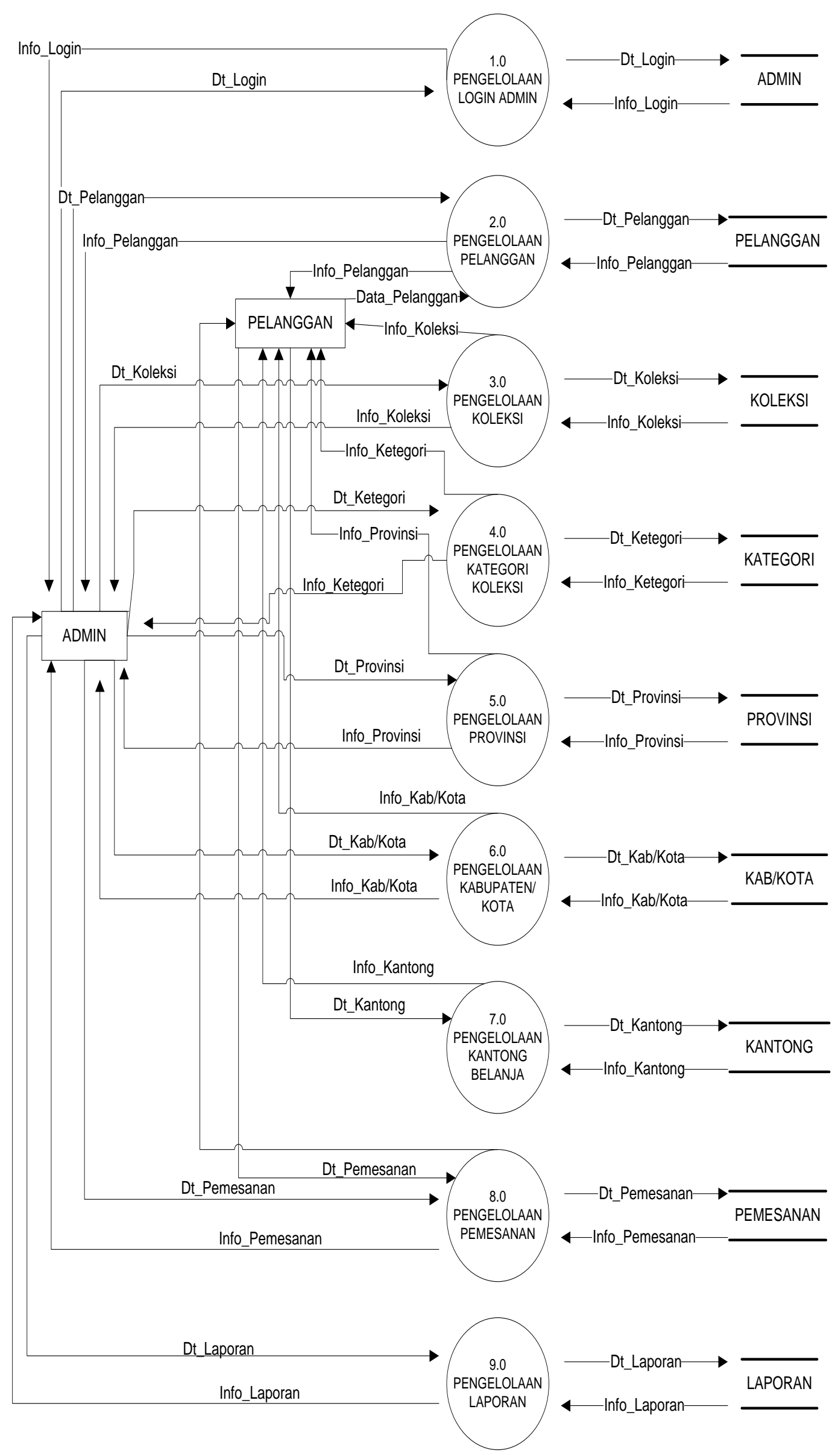

Gambar 2 Data Flow Diagram (DFD) Level 1 
Tabel 1 Proses DFD Level 1

\begin{tabular}{|l|l|}
\hline Pengelolaan Login Admin & $\begin{array}{l}\text { Proses yang mengelola data-data pengelola } \\
\text { sistem }\end{array}$ \\
\hline Pengelolaan Pelanggan & $\begin{array}{l}\text { Proses yang mengelola segala sesuatu yang } \\
\text { berkaitan dengan data Data Pelanggan }\end{array}$ \\
\hline Pengelolaan Koleksi & $\begin{array}{l}\text { Proses yang mengelola segala sesuatu yang } \\
\text { berkaitan dengan data Koleksi Sepatu }\end{array}$ \\
\hline Pengelolaan Kategori & $\begin{array}{l}\text { Proses yang mengelola segala sesuatu yang } \\
\text { berkaitan dengan data Kategori Sepatu }\end{array}$ \\
\hline Pengelolaan Provinsi & $\begin{array}{l}\text { Proses yang mengelola segala sesuatu yang } \\
\text { berkaitan dengan data provinsi }\end{array}$ \\
\hline Pengelolaan Kab/Kota & $\begin{array}{l}\text { Proses yang mengelola segala sesuatu yang } \\
\text { berkaitan dengan data Kabupaten/Kota }\end{array}$ \\
\hline Pengelolaan Kantong Belanja & $\begin{array}{l}\text { Proses yang mengelola segala sesuatu yang } \\
\text { berkaitan dengan data Kantong Belanja }\end{array}$ \\
\hline Pengelolaan Pemesanan & $\begin{array}{l}\text { Proses yang mengelola segala sesuatu yang } \\
\text { berkaitan dengan data Pemesanan }\end{array}$ \\
\hline Pengelolaan Laporan & \begin{tabular}{l} 
Proses yang berfungsi untuk pembuatan laporan \\
\hline
\end{tabular}
\end{tabular}

Tabel 2 Aliran Data DFD Level 1

\begin{tabular}{|l|l|}
\hline \multicolumn{1}{|c|}{ Nama } & \multicolumn{1}{c|}{ Deskripsi } \\
\hline Dt_Login & Data mengenai pengelola sistem \\
\hline Dt_Pelanggan & Data mengenai Pelanggan \\
\hline Dt_Kategori & Data mengenai kategori sepatu \\
\hline Dt_Koleksi & Data mengenai koleksi sepatu \\
\hline Dt_Provinsi & Data mengenai provinsi \\
\hline Dt_Kab/Kota & Data mengenai kabupaten/kota \\
\hline Dt_Kantong & Data mengenai kantong belanja \\
\hline Dt_Pemesanan & Data mengenai pemesanan \\
\hline Dt_Laporan & Data mengenai Laporan \\
\hline Info_Login & Informasi mengenai pengelola sistem \\
\hline Info_Pelanggan & Informasi mengenai pelanggan \\
\hline Info_Koleksi & Informasi mengenai koleksi sepatu \\
\hline
\end{tabular}




\begin{tabular}{|l|l|}
\hline Info_Kategori & Informasi mengenai kategori Sepatu \\
\hline Info_Provinsi & Informasi mengenai provinsi \\
\hline Info_Kab/Kota & Informasi mengenai kabupaten/kota \\
\hline Info_Kantong & Informasi mengenai kantong belanja \\
\hline Info_Transaksi & Informasi mengenai transaksi \\
\hline Info_Laporan & Informasi mengenai laporan \\
\hline
\end{tabular}

\subsection{Perancangan Input}

Desain input merupakan gambaran dalam pembuatan halaman antarmuka. Desain input bisa dilihat pada penjelasan dan gambar berikut nya.

1. Desain Login

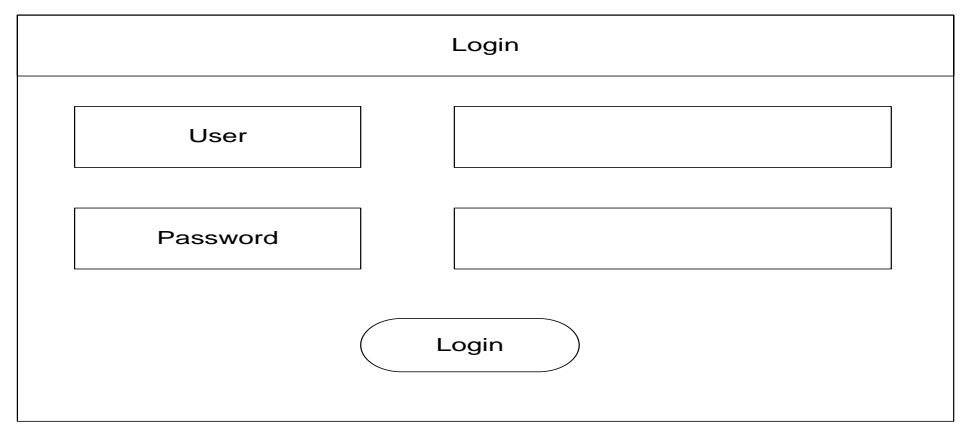

Gambar 3 Desain Login

Gambar diatas merupakan perancangan login, sebelum masuk ke sistem pelanggan atau ataupun admin diharus login terlebih dahulu. Hal ini berfungsi sebagai keamanan.

2. Desain Form Lupa Password

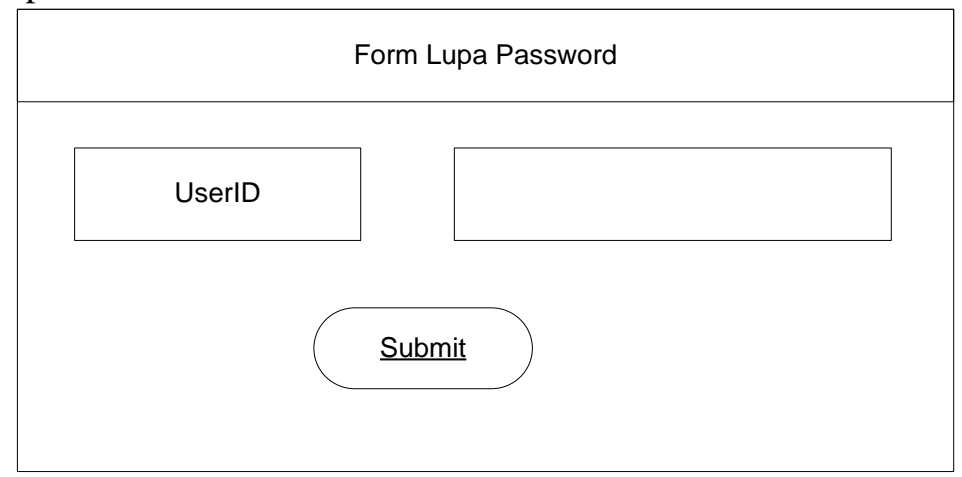

Gambar 4 Form Lupa Password

Pada aplikasi ini dibutuhkan form lupa password jika pelanggan lupa password, maka dia mengakses form ini agar dapat kembali menggunakan akunnya.

\subsection{Perancangan Output}

Desain output merupakan gambaran dalam pembuatan halaman antarmuka. Desain output Aplikasi Penjualan Sepatu Berbasis Web Pada Toko Stephen bisa dilihat pada penjelasan dan gambar berikut nya.

1. Halaman Utama 


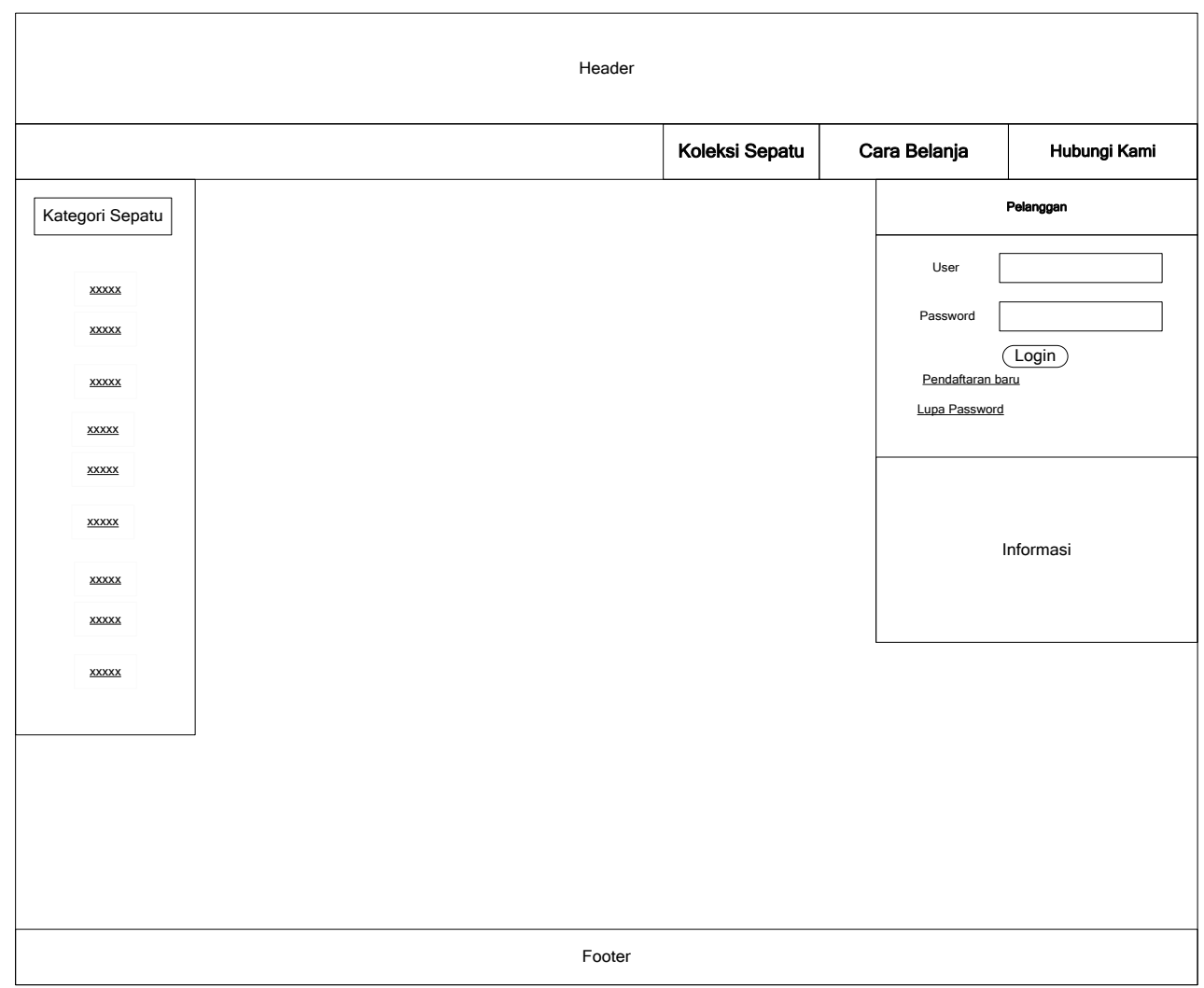

\section{Gambar 5 Halaman Utama}

Ketika pertama kali mengakses website, maka server akan menampilakan halaman utama. Gambar diatas merupakan perancangan halaman utama Aplikasi Penjualan Berbasis Web Pada Toko Stephen. Melalui halaman utama pelanggan bisa melihat koleksi sepatu dengan mengklik link menu atas.

2. Halaman Koleksi Sepatu

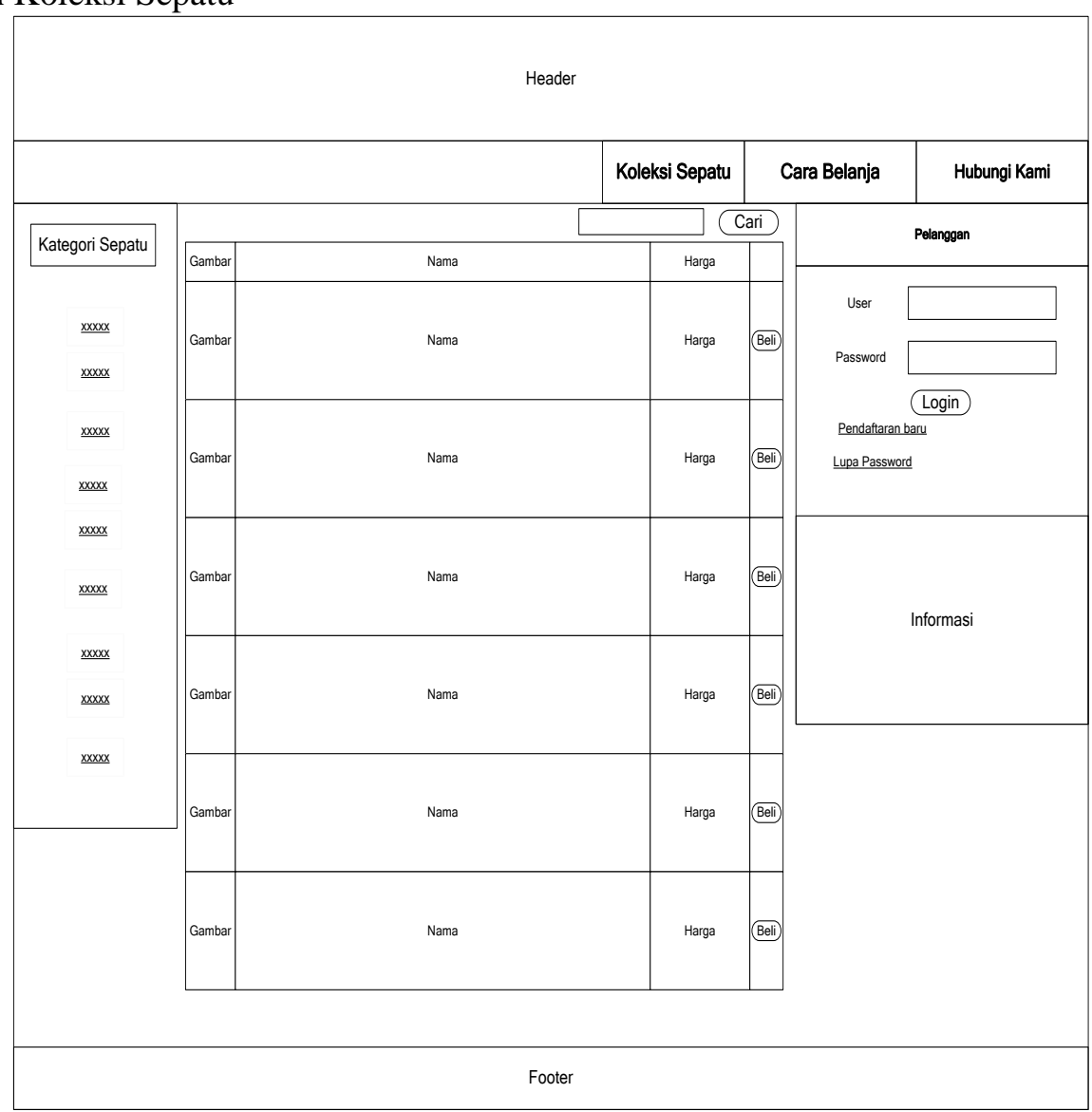

\section{Gambar 6 Halaman Koleksi Sepatu}


Halaman koleksi sepatu menampilkan data-data sepatu yang tersedia didalam database. Untuk mengisi kantong belanja yaitu dengan mengklik tombol beli pelanggan diharus login terlebih dahulu. Halaman koleksi sepatu bisa diakses oleh pelanggan dalam kondisi login atau pun tidak.

\section{IMPLEMENTASI DAN PENGUJIAN SISTEM}

Implementasi merupakan tahap dimana sistem siap dioperasikan pada keadaan sebenarnya, sehingga akan diketahui sistem yang dibuat benar - benar dapat menghasilkan tujuan yang ingin dicapai.

1. Halaman Utama Toko Sepatu Stephen

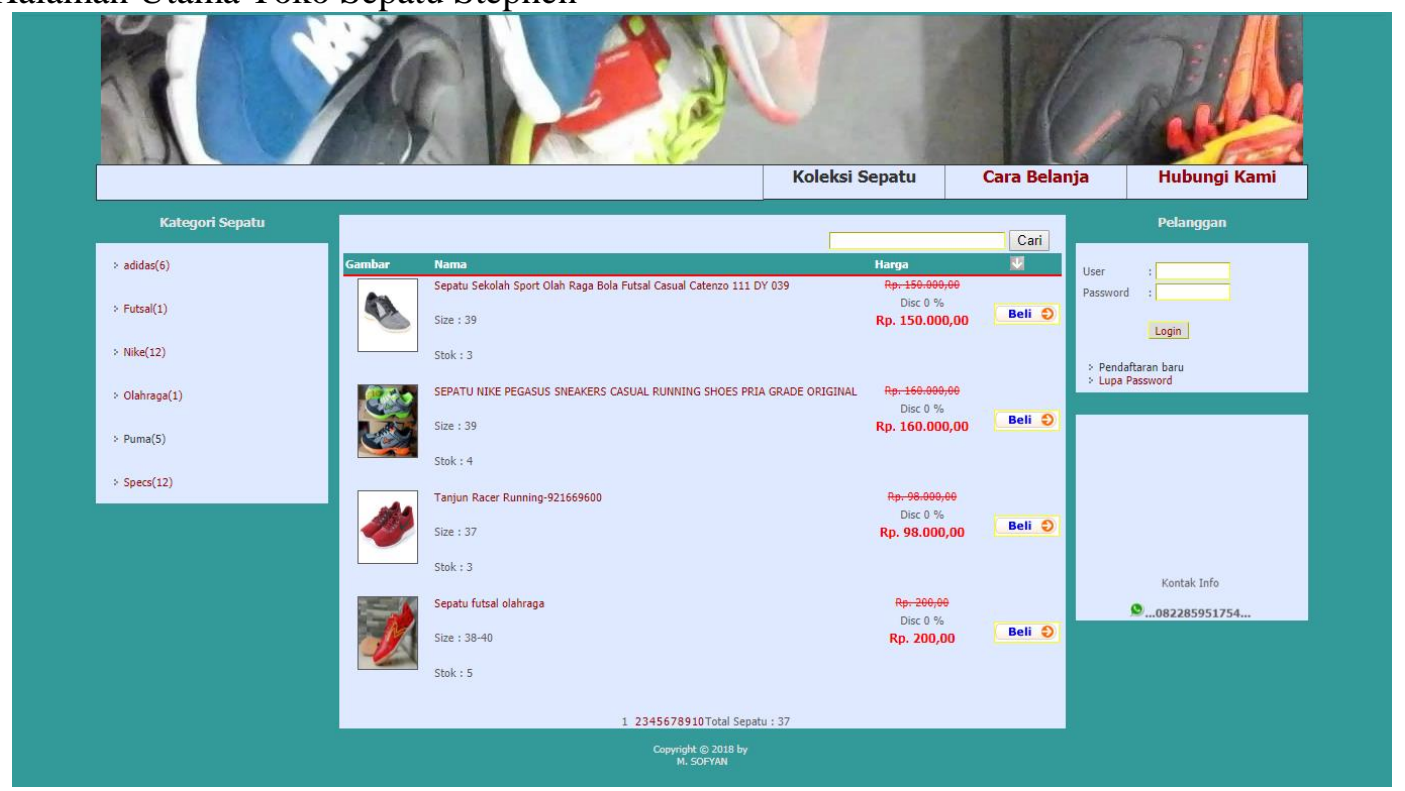

Gambar 7 Halaman Utama

Gambar 7 Halaman Utama diatas merupakan tampilan awal ketika membuka website toko sepatu. Menu menu terdapat di atas yaitu koleksi sepatu, cara belanja, hubungi kami. Dan isi tampil sepatu berdasarkan kategori. Di menu sebelah kanan terdapat menu login, melalui menu ini pelanggan bisa masuk atau mendaftar dan lupa password. 
2. Halaman Kantong Belanja Toko Sepatu Stephen

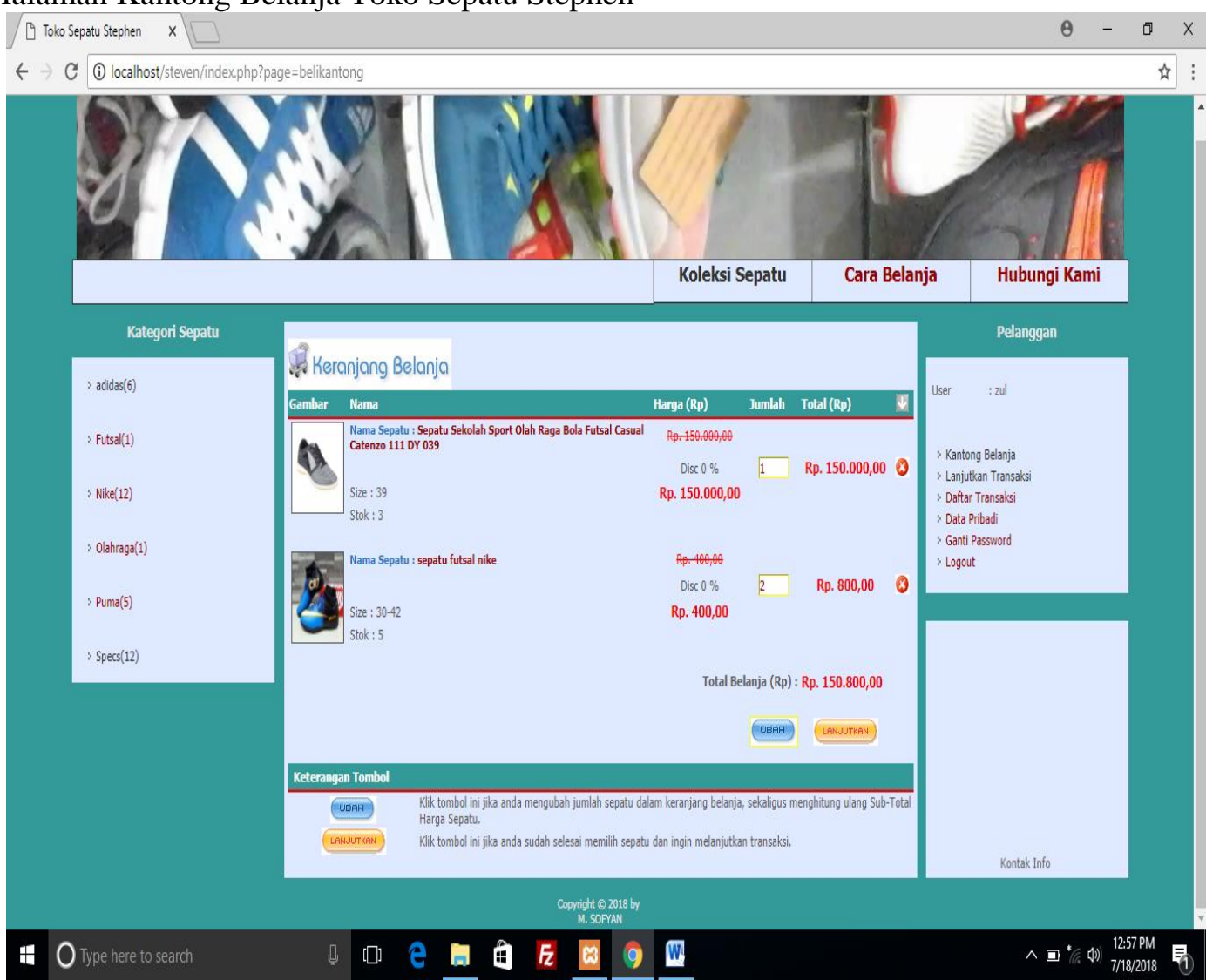

Gambar 8 Halaman Kantong Belanja

Gambar 8 Halaman Kantong Belanja. Setelah mengklik beli di halaman koleksi sepatu, maka pelanggan akan diarahkan ke kantong belanja. Melalui halaman ini pelanggan bisa kembali ke menu sebelum nya dengan mengklik tombol kembali ke katalog sepatu. Dan mengisi kantong belanja kembali. Untuk mengubah jumlah buku yang akan dibeli isikan jumlah buku, lalu klik tombol ubah. Untuk melanjutkan transaksi klik lanjutkan. Akan muncul detail transaksi yang akan menampilkan seluruh total harga transaksi. 
3. Halaman Daftar Sepatu Admin Toko Sepatu Stephen

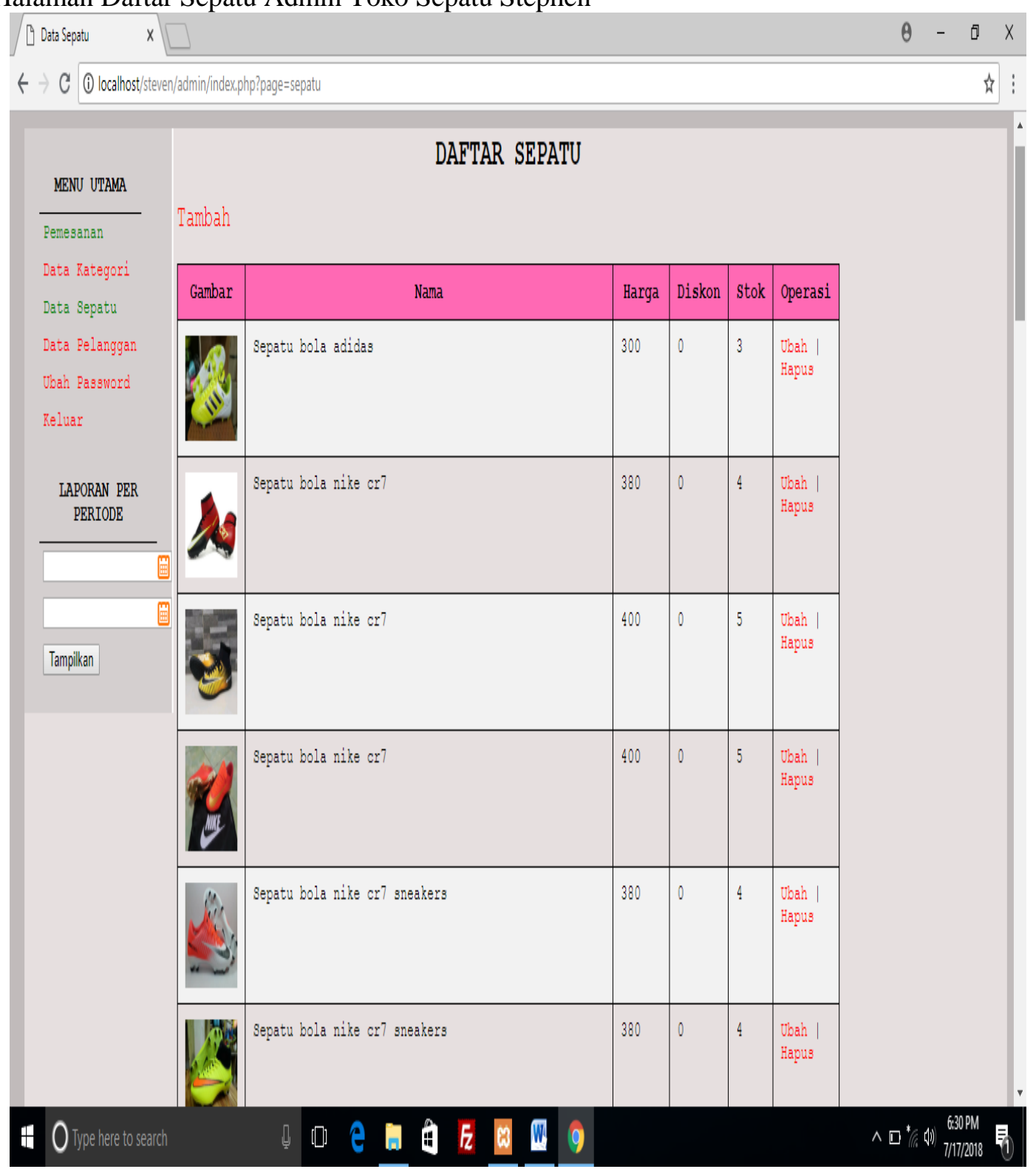

Gambar 9 Halaman Daftar Sepatu Admin

Gambar 9 Halaman Daftar Sepatu Admin. Setalah proses login berhasil barulah admin bisa mengakses halaman ini. Melalui halaman ini admin ditampilkan informasi berupa data-data tentang koleksi sepatu. Untuk menambah data koleksi sepatu klik tombol tambah, untuk mengubah data koleksi sepatu klik tombol ubah dan untuk menghapus klik tombol hapus di paling sebelah kanan.

\section{KESIMPULAN}

1. Sistem Informasi Penjualan Sepatu Berbasis Web Pada Toko Stephen memperluas pemasaran

2. Sistem Informasi Penjualan Sepatu Berbasis Web Pada Toko Stephen mempermudah pelanggan dalam pembelian

3. Sistem Informasi Penjualan Sepatu Berbasis Web Pada Toko Stephen memanfaatkan teknologi berbasis web sebangai pemaran 


\section{DAFTAR PUSTAKA}

Abdurahman, H., \& Ririh, A. R. (2014). Aplikasi Pinjaman Pembayaran Secara Kredit Pada Bank Yudha Bhakti.

Ahmadi, C., \& Hermawan, D. (2013). E-Business \& E-Commerce. Yogyakarta: Andi.

Alfiasca, P. R., Supriyanto, A., \& Sudarmaningtyas, P. (2014). Rancang Bangun Sistem Informasi Manajemen Arsip Rumah Sakit Bedah Surabaya Berbasis Web.

Andi, L. M. (2016). Perancangan Sistem Informasi Pemasaran Dan Penjualan Berbasis Smartphone (Android) Pada Depot Air Minum.

Andri, K. (2008). Perancangan Sistem Informasi Dan Aplikasi. Yogyakarta: Gava Media.

Eko, H. (2014). Pembuatan Sistem Informasi Perpustakaan Berbasis Website Pada Sekolah Menengah Pertama Negeri 1 Donorojo Kabupaten Pacitan.

Fikri, Z. (2012). Analisis Dan Perancangan Sistem Informasi Rumah Makan H. Basuki Riau Berbasis Client Server.

Hamim, T. (2014). Analisis Serta Perancangan Informasi Melalui Pendekatan UML. Yogyakarta: Andi.

Ismal, R. N., \& Dahlan, A. (2013). Pembuatan Sistem Informasi Penjualan Pada Ade Jaya Ponsel Dengan Menggunakan Visual Basic.

Ivan, W. A., Alicia A. E. Sinsuw, S., Sary D. E. Paturusi, S., \& xaverius B. N. Najoan, S. (2014). Perancangan Sitem Informasi Data Alumni Fakultas Teknik Unsrat Berbasis Web.

Lisa, P. (2012). Analisis Dan Perancangan Sistem Informasi Penjualan Menggunakan Java Server Pages Serta Pengawasan Stok Menggunakan Android.

Marjito, \& Gina, T. (2016). Aplikasi Penjualan Online Berbasis Android .

Markito, L., Wahyu, S. E., \& Sukadi. (2013). Pembangunan Sistem Informasi Penjualan Pada Toko Harapan Sentosa Elektronik Kecamatan Kebonagung Kabupaten Pacitan.

Marlina, E., \& Fatmasari. (2016). Perancangan Aplikasi Pembelajaran Matematika Dengan Rumus Bangun Datar Dan Ruang Untuk Siswa Smp Frater Makasar.

Muhammad, S. (2012). Perancangan Sistem Aplikasi Pembuatan Roster Mata Kuliah Pada Perguruan Tinggi.

Nurhayani. (2014). Sistem Informasi Pendaftaran Mahasiswa Baru Di Amik Sigma Palembang.

Puspitosari, H. A. (2010). Having Fun With Adobe Dreamweaver Cs4.

R Faradistia, P. (2013). Motivasi, Jenjang Karir dan Disiplin Kerja Pengaruhnya Terhadap Kinerja Karyawan Pada PT. BANK SULUT Cabang Calaca.

Reza, P. A., \& Krisnawati. (2013). Analisis Dan Perancangan Sistem Informasi Penerimaan Peserta Didik Baru Berbasis Website Pada Smp Negeri 2 Mojosongo Boyolali.

Sanja, K., \& Siska, I. (2015). Perancangan Sistem Informasi Penjualan Helm Pada Toko Helm Swaka Pacitan. 
Septi, L., \& Sari Shinta Wellia, M. (2015). Perancangan Aplikasi Mobile E-Commerce Berbasis Android Pada Violet Fashion Jepara.

Sidik, B. (2014). Pemrograman Web Php. Bandung: Informatika Bandung.

Silvia, Leonita, C., Virginia, Jaya, C. Y., \& Sevani, N. (2015). Aplikasi Diagnosis Karies Pada Gigi Manusia Berbasis Web.

Subekti, M. (2004). Sistem Manajemen Basis Data. Bogor: Ghalia Indonesia.

Sutabri, T. (2012). Analisis Sistem Informasi. Yogyakarta: Andi.

Syachbana. (2011). Sistem Informasi Akademik Berbasis Multimedia Pada Lembaga Pendidikan Palembang Technology.

Syafrin, S. (2011). Analisis Dan Perancangan Sistem Informasi perpustakaan Man Model Kupang.

Taupik, K. O., Irfan, M., \& Nurpianti, A. (2013). Pembuatan Aplikasi Anbiyapedia Ensiklopedi Muslim Anak Berbasis Web.

Tohari, H. (2014). Analisis Serta Perancangan Sistem Informasi Melalui Pendekatan UML. Yogyakarta: Andi. 